\title{
DEFYING ONE-PERSON, ONE-VOTE: PRISONERS AND THE "USUAL RESIDENCE" PRINCIPLE
}

\author{
ROSANNA M. TAORMINA ${ }^{\dagger}$
}

\section{INTRODUCTION}

Criminal disenfranchisement laws in forty-eight states and the District of Columbia deny the right to vote to all convicted adults in prison.' Thirty-two states also disenfranchise felons on parole; thirty disenfranchise those on probation; and thirteen bar ex-offenders who have fully served their sentences from voting for the remainder of their lives. ${ }^{2}$ In the 1974 case of Richardson $v$. Ramirez, ${ }^{3}$ the Supreme Court addressed the constitutionality of such laws. In that case, the Court held that the constitutional right to Equal Protection of the Laws ${ }^{4}$ does not require a state to permit felons to vote." The Court reasoned that exclusion of felons from the franchise was a historically accepted practice and may be lawful when applied equally to all felons. $^{6}$ Despite the Supreme Court's definitive holding, critics of felon disenfranchisement laws have not been silenced. Several decades

${ }^{\dagger}$ A.B. 1999, Dartmouth College; J.D. Candidate 2004, University of Pennsylvania. I owe a debt of gratitude to my Executive Editor, Christopher Seaman, for the many hours he dedicated selflessly to making this a better piece. Thanks are also due to Professor Nathaniel Persily for sharing with me his time, expertise, and many suggestions (not all of which were taken, explaining any errors that may exist). Finally, I would like to acknowledge the University of Pennsylvania Law Review as a whole, for providing me with the opportunity to publish this piece and for two years of support and comradery.

${ }^{\prime}$ See Appendix. For an in-depth discussion of the development and effects of felon disenfranchisement laws, see generally JAMIE FELLNER \& MARC MAUER, LOSING THE VOTE: THE IMPAGT OF FELONY DISENFRANCHISEMENT LAWS IN THE UNITED STATES (1998); Marc Mauer, Mass Imprisonment and the Disappearing Voter, in INVISIBLE PUnishment: THE COllateral CONSEQUENCES OF MASS IMPRISONMENT 50 (Marc Mauer \& Meda Chesney-Lind eds., 2002); Developments in the Law-The Law of Prisons, 115 HARV. L. REV. 1838, 1939-63 (2002).

${ }^{2}$ See Appendix.

3418 U.S. 24 (1974).

${ }^{4}$ U.S. CONST. amend. XIV, § 2.

${ }^{5} 418$ U.S. at 5456 .

${ }^{6}$ Id. at 52-56. 
after the Ramirez decision, the constitutional difficulties inherent in such laws continue to be examined with zeal. ${ }^{7}$

The issue this Comment addresses is not the constitutionality of felon disenfranchisement laws, but how those laws affect the constitutionality of redistricting procedures in state and federal legislative districts. In 1963, Justice Douglas, writing for the Court in Gray v. Sanders, ${ }^{8}$ declared, "[t] he conception of political equality from the Declaration of Independence, to Lincoln's Gettysburg Address, to the Fifteenth, Seventeenth, and Nineteenth Amendments can mean only one thing-one person, one vote." While Gray dealt with the weight of a person's vote within a previously designated geographical unit, ${ }^{10}$ the one-person, one-vote doctrine spilled over into the Court's jurisprudence in examining constitutional challenges to the drawing of congressional and legislative districts. One year after Gray, the Court established that the Constitution imposes a fundamental requirement on those charged with congressional and legislative redistrictingpopulation equality." "In practical terms, population equality means that each district in an apportionment plan should have roughly, if

7 See, e.g., Woodruff v. Wyoming, No. 01-8078, 2002 WL 31243550, at *2-3 (10th Cir. Dec. 3, 2002) (dismissing convicted felon's claim that his disenfranchisement violated the Equal Protection Clause); Howard v. Gilmore, No. 99-2285, 2000 WL 203984, at $* 1$ (4th Cir. Feb. 23, 2000) (denying convicted felon's assertion that his disenfranchisement violates various provisions of the federal Constitution, including the Equal Protection Clause); Johnson v. Bush, 214 F. Supp. 2d 1333, 1337-38 (S.D. Fla. 2002) (holding that Florida's felon disenfranchisement law does not violate the Equal Protection Clause); NAACP v. Ridge, No. CIV. A. 00-2855, 2000 WL 1146619, at *1 (E.D. Pa. Aug. 14, 2000) (denying plaintiffs' request for an injunction against Pennsylvania's felon disenfranchisement law); see also Martine J. Price, Note, Addressing Ex-Felon Disenfranchisement: Legislation $v$. Litigation, 11 J.L. \& POL'Y 369, 376-84 (2002) (recounting various challenges to felon disenfranchisement laws under the Equal Protection Clause).

372 U.S. 368 (1963).

${ }^{9} I d$. at 381 .

10 The Gray' court held:

Once the geographical unit for which a representative is to be chosen is designated, all who participate in the election are to have an equal vote-whatever their race, whatever their sex, whatever their occupation, whatever their income, and wherever their home may be in that geographical unit. This is required by the Equal Protection Clause of the Fourteenth Amendment. Id. at 379 .

1 See Reynolds v. Sims, 377 U.S. 533, 577 (1964) (establishing that "the Equal Protection Clause requires that a State make an honest and good faith effort to construct districts, in both houses of its legislature, as nearly of equal population as is practicable"); Wesberry v. Sanders, 376 U.S. 1, 7-8 (1964) (holding that congressional districts must be redrawn so that "as nearly as is practicable one man's vote in a congressional election is ... worth as much as another's"); see also J. GERALD HEBERT ET AL., THE Realists' Guide to Redistricting: Avoiding THE Legal. Pitfalls 1-11 (2000) 
each district in an apportionment plan should have roughly, if not precisely, the same number of people as every other district." ${ }^{\prime 2}$ As will be discussed in Part II, the Court has been strict in enforcing this requirement.

The problem this Comment addresses arises when we examine how states conduct redistricting. In most states, redistricting is based on data from the decennial census. ${ }^{13}$ For purposes of the census, felons are counted where they are imprisoned, not, for example, where they were arrested or where they once resided. ${ }^{14}$ Thus, in states that disenfranchise their prison population, the result of current districting practices will be districts with equal population in theory only. In reality, however, the percentage of eligible voters will vary significantly will vary significantly across district lines. Assuming perfect voter turnout, the victorious candidate in a prison system district will have been elected by fewer people than the candidate in a district with no prison. Even considering the fact that voter turnout will vary across districts, an elected official in a no-prison district will effectively be responsible for, and accountable to, more constituents than the official whose district contains a large, disenfranchised prison population.

(discussing the history of the Court's one-person, one-vote jurisprudence); NAT'L CONFERENCE OF STATE LEGISLATURES, REDISTRICTING LAW 2000, at 1-2 (1999) [hereinafter REDISTRICTING LAW 2000] (noting a shift in population demographics after World War I and describing the major Supreme Court redistricting cases of the 1960s); Richard K. SCHER ET AL., Voting Rights and Democracy: THE LaW and Politics OF DISTRICTING 19-29 (1997) (discussing the history of gerrymandering and malapportionment, and the particular problems faced by the Supreme Court and the states in the 1960s due to disproportionate population growth); Peyton McCrary, Bringing Equality to Power: How the Federal Courts Transformed the Electoral Structure of Southern Politics, 1960-1990, 5 U. PA. J. CONST. L. 665, 667, 675-81 (2003) (describing the Supreme Court's "reapportionment revolution").

${ }^{12}$ HEBERT ET AL., supra note 11 , at 1.

${ }^{13}$ See Karcher v. Daggett, 462 U.S. 725, 731 (1983) (holding that states must redistrict "using the best census data available"); see also HEBERT ET AL., supra note 11, at 2 ("States engaged in congressional or state-legislative redistricting have ordinarily used the population figures generated by the federal decennial census.").

See District of Columbia v. United States Dep't of Commerce, 789 F. Supp. 1179, 1180 (D.D.C. 1992) ("[T]he Census Bureau has developed a set of special enumeration and residence rules for ... persons living in group quarters, including prisons. Residents of group quarters are enumerated as residents of the locality where the quarters are located ...."); U.S. Census Bureau, Facts About Census 2000 Residence Rules, at http://www.census.gov/population/www/censusdata/resid_rules.html (last modified Apr. 25, 2003) (stating that prisoners are counted at the institution where they are imprisoned); see also U.S. CENSUS BuREAU, UNITED STATES CENSUS 2000, FORM D-61A, available at http://www.census.gov/dmd/www/pdf/d61a.pdf (last visited Nov. 1, 2003) (instructing census respondents not to include members of their household institutionalized in a correctional facility). 
The result is the unequal weighting of votes across district lines-a practice that does not stand on firm constitutional ground.

Counting prisoners for redistricting purposes in the districts in which they are imprisoned is legally problematic on both constitutional and statutory levels. As previously mentioned, such a practice cannot be squared with the constitutional requirement of one-person, one-vote. Additionally, this practice effectively runs afoul of Section 2 of the Voting Rights Act of $1965,{ }^{15}$ which prohibits redistricting plans that have a dilutive effect on the voting strength of racial minorities. ${ }^{16}$ The practice in question may violate the Act because it often has the effect of diluting racial blocs or making it appear as though a bloc exists when in fact one does not. Though Voting Rights Act litigation is complex, a discussion of the possible clash between the Act and the practice of counting felons where they are imprisoned for redistricting purposes is warranted.

Additional questions arise beyond the legal framework developed in this Comment. If it is unconstitutional to count prisoners where they are imprisoned for redistricting purposes, then where should they be counted? The counting of members of the military, college students, children, and noncitizens raises similar problems. How should we deal with these populations? What legislative alternatives are there for counting prisoners? And what is the ultimate policy solution for these issues? Finally, if state legislatures, which are ultimately responsible for redistricting, do not act to correct the identified constitutional and statutory infirmities, what is the proper way to litigate this issue? Who has standing? What relief should be sought? Many of these questions lie outside the scope of this Comment and will not be answered here. It is important, however, to acknowledge their existence so that others may pick up where this Comment leaves off.

Part I of this analysis discusses the history of the Supreme Court's one-person, one-vote jurisprudence. Part II addresses the Court's notion of perfect population equality and its standards for evaluating federal congressional and state legislative redistricting plans. In Part

${ }^{15}$ Pub. L. No. 89-110, 79 Stat. 437 (codified as amended at 42 U.S.C. $\$ \S 1971,1973$ to $1973 \mathrm{bb}-1$ (2000)).

${ }^{10}$ See, e.g., Thornburg v. Gingles, 478 U.S. 30, $78-79$ (1986) (holding that redistricting plans which "ha[ve] the effect of diluting the minority vote" violate Section 2's prohibition on electoral changes that have a "discriminatory effect"); see also infra Part VI.B (discussing the standard for establishing discriminatory effect under Section 2 of the Voting Rights Act). 
III, the analysis shifts to a discussion of the decennial Census and the usual residence principle as they apply to the counting of the United States prison population. Part IV examines the constitutional clash between the Court's one-person, one-vote jurisprudence and the Census' usual residence principle. Part V briefly addresses other populations to which the usual residence principle applies-college students, members of the military, children, and noncitizens-and distinguishes them from the prison population. Part VI is an analysis of the collision between the usual residence principle as applied to prisoners and the Voting Rights Act of 1965. Finally, Part VII offers possible solutions to the constitutional and statutory problems presented by the usual residence principle.

\section{THE History OF ONE-PERSON, ONE-VOTE}

Article I, Section 2 of the United States Constitution reads in part: "[ $t]$ he House of Representatives shall be composed of Members chosen every second Year by the People of the several States.... [and] Representatives... shall be apportioned among the several States... according to their respective numbers ...."17 The Supreme Court has relied on this section of the Constitution to formulate its one-person, one-vote population equality requirement for congressional districts. ${ }^{18}$ Because Article I, Section 2 only speaks to how representatives in our federal system are to be apportioned, the Court has relied on the Equal Protection Clause of the Fourteenth Amendment ${ }^{19}$ to extend the one-person, one-vote requirement to state legislative districts. ${ }^{20}$ Although the Court's standards for population deviation are more lenient for state legislative districts than congressional districts, ${ }^{21}$ the Court is nonetheless strict in its review of state districting practices.

${ }^{17}$ U.S. CONST. art. I, $\$ 2$.

${ }^{18}$ See HEBERT ET AL., supra note 11, at 3 ("The Supreme Court has interpreted [Article I, Section 2] to mean that only a very small amount of [population] deviation is acceptable within a State's congressional redistricting plan.").

19 U.S. CONST. amend. XIV, $\$ 1$.

${ }^{20}$ See generally Reynolds v. Sims, 377 U.S. 533 (1964) (affirming decision invalidating Alabama's legislative apportionment on equal protection grounds); Baker v. Carr, 369 U.S. 186 (1962) (remanding for consideration of an equal protection claim to Tennessee's legislative districts).

${ }^{21}$ A total population deviation of less than ten percent among state legislative districts generally requires no justification from state officials, but courts may require a justification for a deviation as small as ten people when analyzing federal congressional districts. Compare Voinovich v. Quilter, 507 U.S. 146, 161 (1993) (holding that, "as a general matter, ... [a legislative] apportionment plan with a maximum population 
The Court did not always adhere to a strict review of state districting practices. In fact, when the Court was first asked to review the districting practices of state officials, it declined. In 1946, the Supreme Court was presented with Colegrove v. Green. ${ }^{22}$ In that case, members of the Illinois electorate challenged provisions of Illinois law governing federal congressional districts claiming, inter alia, that the laws violated the United States Constitution. ${ }^{23}$ The voters alleged "that by reason of subsequent changes in population the congressional districts for the election of Representatives in the Congress created by the [Illinois laws] lacked ... approximate equality of population." ${ }^{24}$ Congressional district populations "ranged from a low of 112,000 to a high of $900,000 . "{ }^{25}$ As a result, the vote of a person in the state's largest congressional district was worth one-eighth as much as the vote of a person in the state's smallest district. ${ }^{26}$ Writing for a divided Court, Justice Frankfurter concluded that the voters' claim was not justiciable. "The basis for the suit is not a private wrong, but a wrong suffered by Illinois as a polity." ${ }^{27}$ Accordingly, Frankfurter concluded that "[c]ourts ought not to enter this political thicket. The remedy for unfairness in districting is to secure State legislatures that will apportion properly, or to invoke the ample powers of Congress." ${ }^{28}$

Sixteen years later, however, the Court chose to enter the political thicket of redistricting and has since developed a comprehensive jurisprudence based on the same principle of population equality argued by the Illinois voters in Colegrove. In the 1962 case of Baker $v$. $\mathrm{Carr}^{29}$ plaintiffs challenged the apportionment of members of Ten-

deviation under $10 \%$ " is a "minor deviation [] . . insufficient to make out a prima facie case of invidious discrimination under the Fourteenth Amendment so as to require justification by the State" (quoting Brown v. Thompson, 462 U.S. 835, 842-43 (1983))), and Brown, 462 U.S. at 850 (O'Connor, J., concurring) ("[T]his Court has recognized that a state legislative apportionment scheme with a maximum population deviation exceeding $10 \%$ creates a prima facie case of discrimination."), with Anne Arundel County Republican Cent. Comm. v. State Advisory Bd. of Election Laws, 781 F. Supp. 394, 396 (D. Md. 1991) (requiring justification for a ten-person deviation in Maryland's congressional districts), summarily aff d, 504 U.S. 938 (1992).

328 U.S. 549 (1946).

${ }^{29} I d$. at 550-51.

${ }^{24} I d$.

${ }^{25}$ SCHER ET AL., supra note 11 , at 22.

${ }^{26} I d$.

${ }^{27}$ Colegrove, 328 U.S. at 552.

${ }^{28}$ Id. at 556; see also SCHER ET AL., supra note 11, at 23 (describing the Colegrove decision as a "catch-22" because it required voters to seek relief for their partial disenfranchisement through the political process).

29 369 U.S. 186 (1962). 
nessee's General Assembly, claiming that Tennessee law "denied [plaintiffs] the equal protection of the laws accorded them by the Fourteenth Amendment to the Constitution of the United States by virtue of the debasement of their votes."30 The disparity of population deviations in Tennessee's legislative districts was even more severe than those in the Colegrove case, as "the largest district ... had more than 44 times the population of the smallest district.", Without ruling on the merits of the case, the Court declared that "the mere fact that the suit seeks protection of a political right does not mean it presents a political question." legations of a denial of equal protection present a justiciable constitutional cause of action upon which appellants are entitled to a trial and a decision. The right asserted is within the reach of judicial protection under the Fourteenth Amendment." ${ }^{\text {"33 }}$

In 1963 and 1964, the Court decided three landmark redistricting cases that are now credited with the development of the phrase and principle, "one person, one vote." In Gray v. Sanders, ${ }^{34}$ plaintiffs challenged Georgia's county unit system of voting as a violation of the Fourteenth and Seventeenth Amendments. ${ }^{35}$ The county unit system, ${ }^{36}$ used as the basis for counting votes in the Democratic primary for statewide officials, allocated only $1.46 \%$ of the total unit votes to a county that comprised $14.11 \%$ of Georgia's total population. ${ }^{37}$ Meanwhile, Georgia's smallest county, with only $0.05 \%$ of the State's population, was accorded $0.48 \%$ of the unit vote. ${ }^{38}$ In other words, one unit vote in the largest county represented 92,721 residents, while one unit vote in the smallest county represented only 938 residents. ${ }^{39}$ One resident in the smallest county had the same influence on a candi-

${ }^{30} I$. at $187-88$.

${ }^{31}$ McCrary, supra note 11, at 676.

${ }^{32}$ Baker, 369 U.S. at 209.

${ }^{33}$ Id. at 237.

34 U.S. 368 (1963).

${ }^{95} I d$. at 370 .

${ }^{36}$ The Georgia Constitution allocated a certain number of state representatives (three, two, or one) to each county. Candidates who received the majority of the popular vote in each county carried the county and received two "unit votes" for each state representative in that county. State and federal elections were decided by these "unit votes." Id. at 370-71.

${ }^{37}$ Id. at 371 . This was Fulton County, which includes most of the City of Atlanta. Id.
${ }^{38} I d$.
I9. Id. 
date's nomination as ninety-nine residents in the largest county. ${ }^{40}$ The Court held that this amounted to unequal representation for equal numbers of people. ${ }^{41}$ Justice Douglas, writing for the Court, declared:

Once the geographical unit for which a representative is to be chosen is designated, all who participate in the election are to have an equal vote-whatever their race, whatever their sex, whatever their occupation, whatever their income, wherever their home may be in that geographical unit. This is required by the Equal Protection Clause of the Fourteenth Amendment. ${ }^{42}$

Thus, Georgia's county unit system could not be employed so long as it perpetuated inequality of voting power. ${ }^{43}$ Justice Douglas concluded with a sentence that would be quoted for years to come: "The conception of political equality from the Declaration of Independence, to Lincoln's Gettysburg Address, to the Fifteenth, Seventeenth, and Nineteenth Amendments can mean only one thing-one person, one vote." ${ }^{44}$

Justice Douglas's analysis in Gray opened the door for the Court's decisions in two 1964 cases involving state apportionment practices more common than the county unit system. ${ }^{45}$ The state practices challenged in Wesberry $v$. Sanders ${ }^{46}$ and Reynolds $v$. Sims $s^{47}$ involved the apportionment of federal congressional and state legislative districts, respectively. In Wesberry, voters from the Fifth Congressional District of Georgia challenged the population composition of their district because it was substantially larger than the nine other congressional districts in Georgia. According to the 1960 Census, Georgia's Fifth Congressional District contained 823,680 people, while the average population of Georgia's ten districts was 394,312. " $[S]$ ince there [was] only one Congressman for each district, this inequality of population mean $[t]$ that the Fifth District's Congressman [had] to represent from two to three times as many people as [did] Congressmen

${ }^{40}$ Id.

${ }^{41}$ See, e.g., Wesberry v. Sanders, 376 U.S. 1, 18 (1964) (stating that the Constitution has a "plain objective of making equal representation for equal numbers of people").

42 Gray, 372 U.S. at 379.

43 See $i d$. at 381 (" $[\mathrm{O}]$ nce the class of voters is chosen and their qualifications specified, we see no constitutional way by which equality of voting power may be evaded.").

${ }^{44}$ Id.

45 See SCHER ET AL., supra note 11, at 25-26 (discussing Gray, Wesberry, and Reynolds).

4i 376 U.S. 1 (1964).

477 U.S. 533 (1964).

48 Wesberry, 376 U.S. at 2. 
from some of the other Georgia districts." ${ }^{\text {"9) }}$ Relying on the command of Article I, Section 2 of the United States Constitution-that Representatives be chosen "by the People of the several States" in Wesberry held that "as nearly as is practicable[,] one man's vote in a congressional election is to be worth as much as another's." ${ }^{51}$ The Court reasoned that:

It would defeat the principle solemnly embodied in the Great Compromise-equal representation in the House for equal numbers of peoplefor us to hold that, within the States, legislatures may draw the lines of congressional districts in such a way as to give some voters a greater voice in choosing a Congressman than others.

The second key redistricting case decided in 1964 was Reynolds $v$. Sims. ${ }^{5 y}$ This case involved a series of challenges to the apportionment of Alabama's legislature. ${ }^{54}$ In contrast to Wesberry, which involved a challenge to the state practice of apportioning federal congressional districts, the Court in Reynolds relied on the Equal Protection Clause of the Fourteenth Amendment to ultimately extend its one-person, one-vote tenet to the apportionment or redistricting of both houses of a state's legislature. ${ }^{55}$ The Court held that:

As a basic constitutional standard, the Equal Protection Clause requires that the seats in both houses of a bicameral state legislature must be apportioned on a population basis. Simply stated, an individual's right to vote for state legislators is unconstitutionally impaired when its weight is in a substantial fashion diluted when compared with votes of citizens living in other parts of the State.

Id

${ }^{50}$ U.S. CONST. art. I, $\$ 2, \mathrm{cl} .1$.

51 Wesberry, 376 U.S. at 7-8. The Court did not reach claims that the Georgia statute violated the Due Process Clause, the Equal Protection Clause, and the Privileges and Immunities Clause of the Fourteenth Amendment. Id. at 8 n.10.

Id. at 14.

53 377 U.S. 533 (1964).

${ }^{54}$ On the same day as the Reynolds decision, the Court also decided challenges to five other states in apportioning their state legislatures. See Lucas v. Forty-Fourth Gen. Assembly of Colo., 377 U.S. 713 (1964) (Colorado); Roman v. Sincock, 377 U.S. 695 (1964) (Delaware); Davis v. Mann, 377 U.S. 678 (1964) (Virginia); Md. Comm. for Fair Representation v. Tawes, 377 U.S. 656 (1964) (Maryland); WMCA, Inc. v. Lomezo, 377 U.S. 633 (1964) (New York).

${ }^{55} 377$ U.S. at 571, $574-76$ (rejecting defendants' argument that the Georgia Senate was analogous to the United States Senate and thus did not require equally apportioned districts).

5i Id. at 568 . 
The overall effect of the Court's activity in 1963 and 1964 "was to alter forever the representation in state legislatures and to create far more equity in congressional districts than had existed before. ${ }^{, 57}$

\section{Measuring Population EQuality}

How close must a state get to perfect population equality in order to satisfy the Court's mandate of one-person, one-vote? It is important to note that most courts measure population equality using "overall population deviation" or "total population deviation"-namely, "the difference between the populations of the most heavily, and least heavily, populated districts. ${ }^{, 58}$ This figure can be expressed as a percentage of the ideal population of a district. ${ }^{59}$ For a single-member legislative plan, the ideal population is equal to the total population of a state divided by the number of allotted congressional or state legislative seats. ${ }^{60}$

Perhaps because "[t]he equal population requirements do not rest on the same stone in the constitutional foundation of the Republic," ${ }^{, 1}$ the Court has developed two different legal standards for evalu-

${ }^{57}$ SCHER ET AL., supra note 11 , at 26 . However, as one scholar has noted, Congress's "[o]pposition to the one person, one vote standard" for state legislatures "was initially substantial." McCrary, supra note 11 , at 680 . In 1964, a coalition of Republicans and Democrats in the United States Senate introduced a constitutional amendment that would have permitted at least one house of a state legislature to be apportioned on a basis other than equal population. See id. (discussing a constitutional amendment introduced by Sen. Everett Dirksen (R-Ill.), the minority leader, and Sen. Frank Church (D-Idaho) that would have permitted a deviation from equipopulous districts). This amendment garnered the support of a majority of the Senate, but fell seven votes short of the required two-thirds supermajority. Id. The same year, a proposal by Rep. William Tuck (D-Va.) to "strip the federal courts of all power over state legislative apportionment" was approved by the House, but failed in the Senate. Id.

${ }^{58}$ HeBERT ET AL., supra note 11, at 1; see also REDISTRICTING LAW 2000, supra note 11 , at 22 (referring to "overall population deviation" or "total population deviation" as "overall range" and calling it "[p]erhaps the most commonly used measure" of determining compliance with the one-person, one-vote standard).

${ }^{59}$ See HeberT ET AL., supra note 11, at 1 (explaining that a state with 1000 people and five districts would have perfect population equality-zero percent population deviation-if each of the five districts contained 200 people).

${ }^{60}$ See REDISTRICTING LAW 2000, supra note 11, at 21 (noting that courts have not always used redistricting measures consistently or precisely, which has led to confusion)

Id. at 23 (referring to Court's reliance on Article I, Section 2 of the United States Constitution to justify its population equality requirement for federal congressional districts, while relying on the Equal Protection Clause of the Fourteenth Amendment to justify the requirement for state legislative districts). 
ating federal congressional and state legislative redistricting plans - strict equality and the ten percent rule, respectively. ${ }^{62}$

\section{A. Federal Congressional Districts}

In general, the Court demands strict equality when examining the population make-up of a state's federal congressional districts. ${ }^{63}$ Narrowly considered, strict equality means zero total population deviation. Thus, a sure way to avoid a constitutional one-person, one-vote challenge would be to draw districts with the minimum possible population deviation. ${ }^{64}$ But as will be discussed, the Court has carved out a few narrow exceptions to its strict equality standard that allow for "only a very small amount of deviation" from strict equality. ${ }^{65}$ As will be seen, these exceptions do not bear on the constitutional analysis of counting prisoners where they are imprisoned for redistricting purposes.

Although the Court in Wesberry held that "as nearly as is practicable [,] one man's vote in a congressional election is to be worth as much as another's," ${ }^{66}$ it took several cases in the following decades to hammer out the details of the Court's population equality jurisprudence for congressional districts. In 1969, the Court made its first attempt to "elucidate the 'as nearly as practicable' standard." ${ }^{67}$ The case of Kirkpatrick $v$. Preisler involved a challenge to the composition of Missouri's ten congressional districts. ${ }^{68}$ A 1967 Missouri General Assembly redistricting statute created congressional districts with a total popula-

${ }^{62}$ See HEBERT ET Al., supra note 11, at 1-11 (discussing the two distinct legal standards for determining whether the principle of population equality has been satisfied).

${ }^{63}$ See REDISTRICTING LAW 2000, supra note 11, at 23-28 (surveying the Court's consistent affirmation of the status quo regarding one-person, one-vote standards in congressional redistricting); see also infra text accompanying notes 76-86 (describing the Court's requirements for congressional redistricting since Karcher $v$. Daggett, 462 U.S. 725 (1983)). But cf. HEBERT ET AL., supra note 11, at 5-6 ("As with so many redistricting issues, it is hazardous to speculate precisely which deviations will be acceptable to the courts and which will be struck down.").

${ }^{64}$ HEBERT ET AL., supra note 11, at 3-4 (noting that, in the 1990s, "most [s] tates drew plans in which the total deviation was less than 100 people" and that "[n]ine [s] tates drew plans in which the population of the largest district exceeded that of the smallest district by just one person").

\footnotetext{
${ }^{65} I d$. at 3 .

${ }^{60}$ Wesberry v. Sanders, 376 U.S. 1, 7-8 (1964).

${ }^{67}$ Kirkpatrick v. Preisler, 394 U.S. 526, 528 (1969).

6s Id. at 528-29.
} 
tion deviation of $5.97 \%{ }^{69}$ The Court rejected Missouri's argument "that there is a fixed numerical or percentage population variance small enough to be considered de minimis and to satisfy without question the 'as nearly as practicable' standard. ${ }^{70}$ The Court concluded that "the 'as nearly as practicable' standard requires that the State make a good-faith effort to achieve precise mathematical equality. Unless population variances among congressional districts are shown to have resulted despite such effort, the State must justify each variance, no matter how small."

In 1973, the Court invalidated a Texas redistricting law that resulted in $4.13 \%$ total population deviation ${ }^{72}$-an overall deviation even less than in Kirkpatrick. The plaintiffs presented alternative plans to the Court, enabling it to select a plan that better effectuated the one-person, one-vote principle. ${ }^{73}$ Relying on the holding in Kirkpatrick-permitting only population variances that "are unavoidable despite a good-faith effort to achieve absolute equality, or for which justification is shown" ${ }^{\text {;4 }}$-the Court concluded that the existence of the alternative plans proved that the percentage deviations between districts "were not 'unavoidable,' and the districts were not as mathematically equal as reasonably possible."

The leading case dealing with strict population equality of congressional districts is Karcher $v$. Daggett, ${ }^{76}$ decided in 1983. In that case,

${ }^{69}$ See id. (summarizing the percentage variation from the ideal population for each of Missouri's ten congressional districts). The ideal population for each district was 431,981 . The population of the largest district was $13,542(3.13 \%)$ above the ideal, while the population of the smallest district was $12,260(2.84 \%)$ below the ideal, based on 1960 Census data. Id.

Id. at 530 .

${ }^{n} I d$. at 530-31 (internal citation omitted). The Court rejected several justifications offered by the Missouri General Assembly. Id. at 533-34. Some of the rejected justifications-respecting political subdivisions, distinct economic and social communities of interest, and practical politics-were later accepted as legitimate redistrict criteria by the Court in Karcher v. Daggett, 462 U.S. 725, 740 (1983), and in Abrams $v$. Johnson, 521 U.S. 74, 99-100 (1997). See HEBERT ET AL., supra note 11, at 3-5 (explaining the Karcher court's two-step analysis, where step one considers the size of the deviation, and step two considers the justification for the deviation).

${ }_{72}$ White v. Weiser, 412 U.S. 783, 785 (1973).

${ }^{73}$ Id. at 789 n.6 (highlighting alternate redistricting plans proposed at the trial court level).

${ }^{74}$ Kirkpatrick, 394 U.S. at 531.

${ }^{75}$ White, 412 U.S. at 790. The Court again passed on the state's justifications of avoiding fragmentation of political subdivisions and respect for "constituencyrepresentative relations." Id. at 791. See also supra note 71 (surveying other justifications for population deviation, many of which were later accepted as legitimate).

${ }^{76} 462$ U.S. 725 (1983). 
the plaintiffs challenged New Jersey's congressional redistricting plan that resulted in a total population deviation of less than $0.7 \%$ of an average district, with a difference between the largest and smallest districts of 3674 people. ${ }^{77}$ The Court, with Justice Brennan writing for the majority, struck down the plan as unconstitutional and reaffirmed its position in Kirkpatrick, stating "that there are no de minimis population variations, which could practicably be avoided, but which nonetheless meet the standard of Art. I, $\S 2$, without justification..78 ${ }^{78}$ The plaintiffs were able to demonstrate that a different redistricting plan existed with a maximum population deviation of $0.45 \%$ of the average district, ${ }^{79}$ indicating that the state's adopted plan "was not the product of a good-faith effort to achieve population equality."

Proving a deviation from equal population, however, was not the end of the inquiry. The Court then shifted the burden to the State of New Jersey "to prove that the population deviations in its plan were necessary to achieve some legitimate state objective." of legitimate state objectives offered by the Court were: "making districts compact, respecting municipal boundaries, preserving the cores of prior districts, and avoiding contests between incumbent Representatives," as long as such legislative policies were "consistently applied" in a "nondiscriminatory" manner and the population deviations were "minor." The Court further elaborated on the state's burden, stating that:

The State must, however, show with some specificity that a particular objective required the specific deviations in its plan, rather than simply relying on general assertions. The showing required to justify population deviations is flexible, depending on the size of the deviations, the importance of the State's interests, the consistency with which the plan as a whole reflects those interests, and the availability of alternatives that might substantially vindicate those interests yet approximate population equality more closely. ${ }^{83}$

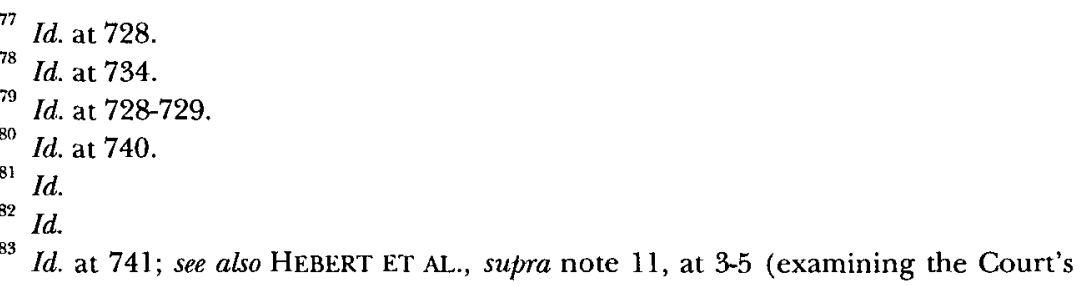
analysis in Karcher). 
Lower federal courts have taken the Supreme Court's one-person, one-vote mandate to heart. ${ }^{84}$ The Federal District Court for the District of Maryland even required the state to justify a total population deviation of only ten people between the largest and smallest districts. ${ }^{85}$ Using the criteria laid out in Karcher, the court accepted the state's justifications that the plan kept three major regions intact, created a minority voting district, and respected incumbent representation. It is important to note that none of the "legitimate state objectives" recognized by Karcher or its progeny come close to justifying the counting of prisoners for redistricting purposes in the districts where they are imprisoned.

\section{B. State Legislative Districts}

Because zero percent population variance is the clearest standard by which to measure one-person, one-vote violations, it is the standard this Comment adopts for its analysis. It is worth noting, however, that the Court has developed a more lenient benchmark for determining whether state legislative districting plans satisfy one-person, one-vote. The Court has enforced a ten percent standard, meaning that a total population deviation of up to ten percent for state legislative districts is generally acceptable without justification. ${ }^{87}$ As previously mentioned, the Court has relied on the Equal Protection Clause to extend its Article I, Section 2 one-person, one-vote requirement in federal congressional districting plans to districting plans for state legislatures. ${ }^{88}$ It has determined, however, that the Equal Protection Clause does not require "perfect population equality" for state legislative

${ }^{84}$ For a list of lower court decisions relying on Karcher to determine if congressional district plans achieve population equality, see REDISTRICTING LAW 2000, supra note 11 , at $26 \mathrm{n} .72$. For an analysis of several lower court, post-Karcher decisions in Texas, Arkansas, California, and Georgia, see HeBERT ET AL., supra note 11, at 5-8.

${ }^{85}$ Anne Arundel County Republican Cent. Comm. v. State Advisory Bd. of Election Laws, 781 F. Supp. 394, 396 (D. Md. 1991), summarily affd, 504 U.S. 938 (1992); see also Vieth v. Pennsylvania, 195 F. Supp. 2d. 672, 676 (M.D. Pa.) (per curiam) (holding that a nineteen-person deviation between the largest and smallest congressional districts in Pennsylvania violated Karcher's interpretation of the constitutional one-person, one-vote principle), appeal dismissed as moot, 537 U.S. 801 (2002).

Id. at 397.

${ }^{87}$ See HEBERT ET AL., supra note 11, at 9-11 (explaining the "ten percent rule" and examples of how the Court has applied it); REDISTRICTING LAW 2000, supra note 11, at 30-43 (discussing the origins of the "ten percent standard" in 1973 and its application to later Supreme Court cases that challenge state legislative districting plans).

${ }^{88}$ See supra Part II.A. 
districts, ${ }^{89}$ so long as the districting plan is "based on legitimate considerations incident to the effectuation of a rational state policy." While the ten percent rule is not unchallengeable, ${ }^{91}$ the Court has stated that a maximum population deviation of under ten percent is not, by itself, sufficient to establish a prima facie violation of the Fourteenth Amendment so as to require state justification. ${ }^{92}$

\section{The Census AND the Usual RESIDENCE PRINCIPLE}

In all of the cases discussed thus far, the Court has relied on data from the decennial United States Census to calculate ideal population, total population deviation, and other figures implicated in challenged statewide redistricting plans. A brief history of the census and its role in reapportionment and redistricting is essential to a comprehensive analysis of the problems presented by the way the census has traditionally counted prisoners. ${ }^{99}$

Article I, Section 2, Clause 3 of the United States Constitution makes it clear that one of the main purposes, if not the main purpose, of the decennial census is to apportion Representatives "among the several States... according to their respective Numbers." ${ }^{.94}$ The

${ }^{89}$ Gaffney v. Cummings, 412 U.S. 735, 743 (1973).

${ }^{90}$ White v. Regester, 412 U.S. 755, 764 (1973) (quoting Reynolds v. Sims, 377 U.S. 533,579 (1964)).

${ }^{91}$ See HeBERT ET AL., supra note 11, at 9 (“[E]ven a deviation below $10 \%$ might be challenged if it was a product of some unconstitutional, irrational, or arbitrary state policy, such as intentionally discriminating against certain groups of voters, certain cities, or certain regions of the State.").

${ }^{92}$ The Court has noted:

[W]e have held that "minor deviations from mathematical equality among state legislative districts are insufficient to make out a prima facie case of invidious discrimination under the Fourteenth Amendment so as to require justification by the State." Our decisions have established, as a general matter, that an apportionment plan with a maximum population deviation under $10 \%$ falls within this category of minor deviations.

Brown v. Thomson, 462 U.S. 835, 842 (1983) (quoting Gaffney, 412 U.S. at 745) (internal citations omitted).

${ }^{93}$ For a comprehensive history of the decennial census and its role in reapportionment and redistricting, see REDISTRICTING LAW 2000, supra note 11, at 6-19. See also Utah v. Evans, 536 U.S. 452, $491-506$ (Thomas, J., concurring in part and dissenting in part) (discussing the history of the Census to discern the "original meaning" of the Census Clause).

${ }^{94}$ Article I, Section 2, Clause 3 reads in relevant part:

Representatives ... shall be apportioned among the several States ... according to their respective Numbers, which shall be determined by adding to the whole Number of free Persons... [and] three fifths of all other Persons. The actual Enumeration shall be made within three Years after the first Meeting of 
"respective Numbers" of the states are determined by an "actual Enumeration" made every ten years ${ }^{95}$-hence, the creation of the decennial census. The Constitution gives Congress the power to effectuate its demand of an "actual Enumeration," and, through Title 13 of the United States Code, Congress delegated the responsibility for conducting a census to the Department of Commerce, ${ }^{97}$ which in turn created the Census Bureau. ${ }^{98}$ Once the census is conducted, the Secretary of Commerce must report the census results to the President of the United States by December 31 of the census year. ${ }^{99}$ The President then uses this information to apportion Representatives in Congress among the several States. The Secretary of Commerce must also report her findings to the individual states no later than one year after the decennial census date. ${ }^{100}$ Most states (and courts) use the information generated by the decennial census to create and review their federal congressional and state legislative redistricting plans. ${ }^{101}$

Thus far, it is unclear why using the information gathered through the decennial census for redistricting purposes would be legally problematic. There are, however, several problems with using these raw data specifically for redistricting purposes. These problems arise as a result of the Census Bureau's development of the "usual residence" principle. According to the Census Bureau, usual residence-the main principle in determining where a person is to be counted for the purpose of the census-"has been defined as the place where the person lives and sleeps most of the time. This place is not necessarily the same as the person's voting residence or legal resi-

the Congress of the United States, and within every subsequent Term of ten Years, in such a Manner as they shall by Law direct.

U.S. ConsT. art I, $\S 2$, cl. 3 . Article I, Section 2, Clause 3 was subsequently amended by Section 2 of the Fourteenth Amendment, which provided in part: "Representatives shall be apportioned among the several States according to their respective numbers, counting the whole number of persons in each State ...." U.S. CONST. amend. XIV, $\S$ 2.

${ }^{95}$ U.S. CONST. art I, $\$ 2$, cl. 3.

${ }^{96} \mathrm{Id}$.

9713 U.S.C. $\$ 2(2000)$.

98 REDISTRICTING LAW 2000, supra note 11, at 7.

9913 U.S.C. $\$ 141$ (b) (2000).

${ }^{100} I d . \S 141(\mathrm{c})$. The decennial census date is April 1 of the year in which the census is administered (e.g., 1980, 1990, 2000). Id. $\$ 141$ (a).

${ }^{101}$ HEBERT ET AL., supra note 11, at 2; REDISTRICTING LAW 2000, supra note 11, at 7. Redistricting is the process of redrawing boundaries of election districts, while reapportionment is the process of reallocating congressional seats among the states or legislative seats within the states. REDISTRICTING LAW 2000, supra note 11, at 7 n.26. 
dence." ${ }^{102}$ This principle affects, among others, the counting of college students, members of the military, and those undergoing drug treatment programs. ${ }^{103}$ Most importantly, the usual residence principle affects the way in which prisoners are counted; it requires census officials to count imprisoned adults and juveniles at the place in which they are institutionalized. ${ }^{104}$

As mentioned in the Introduction, forty-eight states and the District of Columbia deny the right to vote to all convicted adults in prison. ${ }^{105}$ Thirty-two states also disenfranchise felons on parole; thirty disenfranchise those on probation; and thirteen bar ex-offenders who have fully served their sentences from voting for life. ${ }^{106}$ The Court has determined that, standing alone, such laws are constitutional. ${ }^{107}$ The Court, however, has never addressed the constitutional implications that these laws, in combination with the Census Bureau's usual residence principle, may have in the context of state redistricting practices.

\section{ONE-PERSON, ONE-VOTE: CONSTITUTIONAL IMPLICATIONS}

At year end 2002, the Department of Justice estimated that 6.7 million people were on probation, in jail or prison, or on parole-one

102

U.S. Census Bureau, Facts About Census 2000 Residence Rules, at http://www.census.gov/population/www/censusdata/resid_rules.html (last modified Apr. 25, 2003).

${ }^{103}$ Id. One-person, one-vote problems also arise because the census counts children under eighteen and noncitizens in the figures transferred to states for redistricting purposes. However, neither children under eighteen nor noncitizens have the legal right to vote. See 42 U.S.C. $\$ 1971$ (a)(1) (2000) (acknowledging the right of United States cilizens to vote); Id. $\$ 1973 \mathrm{bb}$ (enforcing, under the Twenty-Sixth Amendment, the right to vote of all citizens who are at least eighteen years of age); see also U.S. CONST, amend XXVI, $\$ 1$ ("The right of citizens of the United States, who are eighteen years of age or older to vote shall not be denied or abridged . ..."). While not the main focus of this Comment, these problems will be addressed briefly in Part IV, infra. Counting each of these populations in figures used for redistricting purposes raises serious constitutional difficulties, and a separate article could be written about each group.

U.S. Census Bureau, Facts About Census 2000 Residence Rules, at http:// www.census.gov/population/www/censusdata/resid_rules.html (last modified Apr. 25, 2003).

${ }^{105}$ See supra note 1 and accompanying text.

106 See supra note 2 and accompanying text.

${ }^{107}$ See Richardson v. Ramirez, 418 U.S. 24 (1974) (upholding California's disenfranchisement of ex-felons); cf. supra note 7 (discussing recent challenges to the constitutionality of felon disenfranchisement laws). 
in every thirty-two adults. ${ }^{108}$ The Census Bureau also determined that approximately two million people resided in correctional institutions at the time of the 2000 Census. ${ }^{109}$ Although these individuals cannot vote in most states, they are nonetheless included in the population figures used to calculate the size and location of congressional districts throughout the state. The number of prisoners, in effect, inflates the population of the congressional district in which they are counted. As a result, an individual's vote in a rural congressional district that contains a densely populated correctional institution is weighted more heavily than an individual's vote in a prisonless district. ${ }^{10}$ The inflation of one citizen's voting power at the expense of another's is precisely what the Supreme Court's one-person, one-vote jurisprudence forbids. The Court has stated expressly that "there are no de minimis population variations, which could practicably be avoided, but which nonetheless meet the standard of Article I, Section 2, without justification."111 The justifications accepted by the Court"making districts compact, respecting municipal boundaries, preserving the cores of prior districts, and avoiding contests between incumbent Representatives"112 - are simply not applicable here. The suggestion is not that prisoners, no matter where they are located throughout a state, should be combined to form one discrete congressional district. Rather, as discussed in Part VII, there are several "practicable" solutions to the identified constitutional dilemma that would enable state officials to maintain respect for political subdivisions, compact districts, and other consistently accepted policies. State offi-

108 Lauren E. Glaze, U.S. Dep't of Justice, Probation and Parole in the UNTED STATES, 2002, at 1 (2003), http://www.ojp.usdoj.gov/bjs/pub/pdf/ppus02.pdf (last modified Aug. 18, 2003).

${ }^{109}$ See Kimball Jonas, U.S. Census Bureau, Group Quarters ENumeration 55 app. $C$ (2003) (stating that $1,976,018$ persons were imprisoned nationwide at the time of the 2000 Census), available at http://www.census.gov/pred/www/rpts/E.5\% 20R.pdf; see also PAIGE M. HARRISON \& AlLEN J. BECK, U.S. DEP'T OF JUSTICE, PRISONERS IN 2002, at 1 (2003) ("Overall, the United States incarcerated 2,166,260 persons at yearend 2002."), http://www.ojp.usdoj.gov/bjs/pub/pdf/p02.pdf.

${ }^{110}$ See generally Peter Wagner, Prison Initiative, Importing Constituents: Prisoners and Political Clout in New York 9 (unpublished manuscript, on file with author) ("Every urban prisoner counted as a rural resident decreases the number of 'real' rural residents required for a rural district. As the number of real residents declines, the weight of a vote from a rural resident increases."), available at http://www.prison policy.org/importing/importing_body.pdf (last modified May 20, 2002).

111 Karcher, 462 U.S. at 734; see also supra note 87 and accompanying text (explaining that lower courts have required states to justify deviations of less than twenty people in congressional redistricting plans).

${ }^{112}$ Karcher, 462 U.S. at 740. 
cials responsible for creating redistricting plans simply do not account for the population variations between election districts caused by the application of the usual residence principle to prisoners, nor are they necessarily permitted to do so. ${ }^{113}$ As long as redistricting practices are based on a census that employs the usual residence principle as it now exists, our congressional districts will continue to defy the one-person, one-vote command of Article I, Section 2.

\section{College Students, Members of the Military, CHILDREN, AND NONCITIZENS}

Because sentence durations vary and because convicted adults in certain states will regain their legal right to vote once their time is served, using the usual residence principle to count prisoners presents one-person, one-vote complications similar to those presented in counting college students, noncitizens, and members of the military. The fact that college students and members of the military are counted at their "usual residence" base, respectively-is problematic on the one-person, one-vote front if those individuals choose to vote in their home districts by absentee

119 The Supreme Court has yet to approve of a congressional redistricting plan based on anything but total population as defined by the decennial census. In Kirkpatrick v. Preisler, 394 U.S. 526, 534-35 (1969), the Court rejected Missouri's congressional redistricting plan, which was based on "haphazard adjustments to a scheme based on total population." In dicta, the Court stated: "There may be a question whether distribution of congressional seats except according to total population can ever be permissible under Art. I, $\S 2$. But assuming without deciding that apportionment may be based on eligible voter population rather than total population, the Missouri plan is still unacceptable." Id. at 534. Several lower courts have held that states must depend on total population figures from the decennial census for federal congressional redistricting. See, e.g., Garza v. County of Los Angeles, 918 F.2d 763 (9th Cir, 1990) (rejecting a congressional redistricting plan based on voting age population in favor of a proposed plan based on total population); Travis v. King, 552 F. Supp. 554, 571 (D. Haw. 1982) (holding "that pursuant to article I, $\$ 2$ of the Constitution [,] states must depend on total federal census figures to apportion congressional districts within their boundaries"); see also REDISTRICTING LAW 2000, supra note 11, at 17-18 (discussing the possibility of alternative population bases for redistricting); $c f$. Meeks v. Avery, $251 \mathrm{~F}$. Supp. 245, 249-50 (D. Kan. 1966) (rejecting the proposition that Article I, Section 2 requires states to use decennial census figures in redistricting congressional districts).

${ }^{114}$ See U.S. Census Bureau, Facts About Census 2000 Residence Rules, at http:// www.census.gov/population/www/censusdata/resid_rules.html (last modified Apr. 25, 2003) (defining "usual residence as "the place where the person lives and sleeps most of the time," and noting that " $[t]$ his place is not necessarily the same as the person's voting residence or legal residence"). 
ballot. ${ }^{115}$ This phenomenon is especially troublesome when students choose to relocate after their four years of college education are complete. $^{116}$

Similar problems exist whenever an individual moves out of the district in which she was counted during the decennial census. Americans, however, have always been a highly mobile people, ${ }^{117}$ and it is improbable that one census every ten years would be able to account for the daily variances in population. Rather, it is generally accepted that when some individuals leave an area, others enter. This reasoning, based on the assumption of replacement, can also be extended to justify the usage of census figures that include children under the age of eighteen for redistricting purposes. As young adults enter the voting-age population, deaths result in a commensurate dwindling of that same population.

Ultimately, there will always be population shifts and that is precisely why the Founding Fathers called for reapportionment every ten years. The point here is that groups like college students, members of the military, children, noncitizens, and those prisoners who stand to regain their voting power have the potential (however unlikely in the case of prisoners) to vote in the district in which they are counted. On the other hand, convicted adults in the states that disenfranchise prisoners for life will never vote in the district in which they are counted and have absolutely no potential to do so.

${ }^{115}$ States cannot categorically prohibit absentee balloting by students and military personnel located outside the state at the time of the election. See Carrington v. Rash, 380 U.S. 89 (1965) (holding unconstitutional a Texas law barring all active military personnel from voting in the state); see also Ashira Pelman Ostrow, Note, Dual Resident Voting: Traditional Disenfranchisement and Prospects for Change, 102 COLUM. L. REv. 1954, 1969 (2002) ("Members of the military and student voters have repeatedly been found to have a right to vote in the communities in which they temporarily reside while in the army or attending school ....").

${ }^{116}$ Most state laws, however, permit such individuals to change their residency status and vote in the district where they temporarily reside. See, e.g., Williams v. Salerno, 792 F.2d 323, 328 (2d Cir. 1986) (holding that a per se rule prohibiting students to register at the location of their dormitory violates equal protection); Whatley v. Clark, 482 F.2d 1230, 1233-34 (5th Cir. 1973) (invalidating a Texas statute that prevented college students from registering to vote at their school).

117 See, e.g., Wells v. Rockefeller, 394 U.S. 542, 550 (1969) (Harlan, J., dissenting) (asserting that "our mobile population rapidly renders [census data] obsolete"); SCHER ET AL., supra note 11, at 4 ("Americans are one of the most mobile populations in the world."). 


\section{THE Voting Rights ACT OF 1965}

The counting of imprisoned adults at their prison address for redistricting purposes is legally problematic on both statutory and constitutional levels. ${ }^{118}$ The Voting Rights Act of $1965^{119}$ governs the treatment of race in the redistricting process. This is important because a large racial disparity exists in the current prison population. The following background is key: According to the Bureau of Justice Statistics, sixty-three percent of state prison inmates were racial or ethnic minorities in 2002. ${ }^{120}$ Based on current rates of first incarceration, an estimated thirty-two percent of black males will enter state or federal prison during their lifetime, compared to seventeen percent of Hispanic males and six percent of white males. ${ }^{121}$

\section{A. Section 5 of the Voting Rights Act}

Section 5 of the Voting Rights Act ${ }^{122}$ was enacted in response to "a common practice in some jurisdictions of staying one step ahead of the federal courts by passing new discriminatory voting laws as soon as the old ones had been struck down." ${ }^{123}$ Section 5 is not universally applicable; it applies only to nine states and parts of seven others. ${ }^{124}$ The "covered jurisdictions" are those with a history of racial discrimination in electoral practices, ${ }^{125}$ and for them, Section 5 is "one of the

118 An entirely separate article could be written on the clash between the application of the usual residence principle to prisoners and the Voting Rights Act. Thus, the discussion in this Comment will set out only the basics of the argument.

${ }^{119}$ Pub. L. No. 89-110, 79 Stat. 437 (codified as amended at 42 U.S.C. $\$ \S 1971$, 1973 to $1973 \mathrm{bb}-1(2000))$.

${ }^{120}$ HARRISON \& BECK, supra note 109, at 9.

121 ThOMAS P. BONCZAR, U.S. DEP'T OF JUSTICE, PREVAlenCE OF IMPRISONMENT IN THE U.S. POPULATION, 1974-2001, at 8 (2003), http://www.ojp.usdoj.gov/bjs/pub/ pdf/piusp01.pdf.

${ }_{122} 42$ U.S.C. $\$ 1973 \mathrm{c}(2000)$.

${ }^{123}$ Beer v. United States, 425 U.S. 130, 140 (1976).

12428 C.F.R. pt. 51 app. (2003). The covered jurisdictions are the states of Alabama, Alaska, Arizona, Georgia, Louisiana, Mississippi, South Carolina, Texas, and Virginia, and various counties in California, Florida, Michigan, New Hampshire, New York, North Carolina, and South Dakota. Id.; see also Voting Section, U.S. Dep't of Justice, Section 5 Covered Jurisdictions (listing the states, counties, and townships covered under Section 5), at http://www.usdoj.gov/crt/voting/sec_5/covered.htm (last updated Jan. 28, 2003).

${ }^{125}$ See Redistricting LAw 2000, supra note 11, at 80 (observing that Section 5 focuses on those states that have had a history of "racially discriminatory electoral practices"). 
most significant legal constraints on the redistricting process."126 Section 5 requires covered jurisdictions to submit their redistricting plans to either the Attorney General or the United States District Court for the District of Columbia for administrative or judicial preclearance. ${ }^{127}$ Before granting preclearance, the Attorney General or the District Court must determine that the new redistricting plan "does not have the purpose and will not have the effect of denying or abridging the right to vote on account of race or color, or [membership in a language minority group]." ${ }^{28}$ The effects prong of Section 5 is implicated by the Bureau of Census' usual residence principle.

A redistricting plan that will lead to retrogression, or a worsening of position, in the power of voters belonging to a racial or language minority group runs afoul of Section 5's effects prong. ${ }^{129}$ Minority voting strength can be reduced in two very different ways: (1) by splitting up or "fragmenting" concentrations of minority voters into two or more districts so as to dilute their voting power as a cohesive bloc; ${ }^{130}$ or (2) by "packing" minority voters into one district, reducing their ability to act as influential voting blocs in several separate districts. ${ }^{131}$ When Census officials count incarcerated adults-a majority of whom are members of a racial or ethnic minority group-at their prison address, and the resulting figures are used by states in creating redistricting plans, it can be argued that those states are in effect fragmenting or packing minority concentrations. Counting minority prisoners outside of their communities lessens or fragments minority voting power in the communities from which those prisoners originate. Depending, of course, on the size of the proposed congressional district and the size of the minority prison population, one can also argue that, by including the prison population in a redistricting plan, states

${ }^{126}$ HEBERT ET AL., supra note 11 , at 14.

${ }^{127}$ See 42 U.S.C. $\$ 1973 \mathrm{c}$ (stating that preclearance must be granted for any change in a "standard, practice, or procedure with respect to voting"); Beer, 425 U.S. at 133 (deeming new congressional or legislative redistricting plans to be such a change). For a succinct explanation of Section 5 of the Voting Rights Act of 1965, see HEBERT ET AL., supra note 11, at 14-21.

${ }^{128} 42$ U.S.C. $\$ 1973 c$ (emphasis added).

129 See HeberT ET AL., supra note 11, at 16 ("A change in a State's districting plan is considered to have an impermissibly discriminatory effect under Section 5's 'effects prong' if it will lead to a 'retrogression' in the position of members of a racial or language minority group."); see also Beer, 425 U.S. at 639 ("In other words, the purpose of $\$ 5$ has always been to insure that no voting-procedure changes would be made that would lead to a retrogression in the position of racial minorities ....").

${ }^{130}$ See HEBERT ET AL., supra note 11 , at 17.

191 Id. 
are packing congressional districts with minorities, leading to the appearance of an influential voting bloc where none actually exists. Provided that minority prisoners exist in adequate numbers, the usual residence principle runs directly into the effects prong of Section 5.

The above analysis reaches an obstacle when one considers that retrogression is assessed by comparing the proposed plan to a "benchmark." 132 The benchmark will generally be the districting plan in effect at the time the new plan is proposed. ${ }^{133}$ Because the redistricting plan in effect will most likely have been based on census figures generated using the usual residence principle, the proposed plan will not differ much from the benchmark. ${ }^{134}$ The Attorney General or the United States District Court for the District of Columbia would have to employ a different benchmark-perhaps one that counted prisoners at their last known address or one that did not count permanently disenfranchised prisoners at all-in order for the effects prong of Section 5 to be implicated. That, however, is not what the law requires, so we must turn to Section 2 of the Voting Rights Act for a more practical analysis.

\section{B. Section 2 of the Voting Rights Act}

Section 2 of the Voting Rights Act $^{135}$ applies universally and is aimed at effectuating the Fifteenth Amendment. ${ }^{136}$ Section 2 prohibits minority vote dilution - "the minimization or canceling out of minority voting strength., ${ }^{137}$ In two major cases in $1986^{138}$ and $1994,{ }^{139}$

${ }_{133}^{132} I d$. at 16.

133 Id.

134 But see id. at 16 ("If the current plan is an unconstitutional racial gerrymander or is not legally enforceable under Section 5, the last constitutional, legally enforceable plan used by the State will be designated as the benchmark." (internal citations omitted)).

13542 U.S.C. $\$ 1973(2000)$.

136 HEBERT ET AL., supra note 11, at 22; see also Thornburg v. Gingles, 478 U.S. 30, 43 (1986) (holding that Section 2 "prohibits all states and political subdivisions from imposing any voting qualifications or prerequisites to voting, or any standards, practices or procedures" that have a discriminatory intent or effect (first emphasis added)). For a concise but comprehensive discussion of Section 2 of the Voting Rights Act and the development of the Court's jurisprudence, see HEBERT ET AL., supra note 11, at 2249 .

${ }^{137}$ HEBERT ET AL., supra note 11, at 22; see also Gingles, 478 U.S. at 47 (holding that Section 2 covers claims of minority vote dilution, which exists when the electoral practice or procedure "operate[s] to minimize or cancel out the voting strength of racial [minorities in] the voting population" (quoting Burns v. Richardson, 384 U.S. 73, 88 (1966))); Chandler Davidson, Minority Vote Dilution: An Onerview, in MINORITY VOTE 
the Court developed and expounded upon a three-prong test for determining when a state must create a majority-minority district. ${ }^{140}$ In evaluating a redistricting plan under Section 2, courts and states must ask the following questions: (1) Does the racial or language minority group have sufficient numerosity and geographical compactness to constitute a majority in a single-member district drawn differently?; (2) Is the group politically cohesive?; and (3) Does the white majority vote as a bloc, enabling it to defeat the minority group's preferred candidate $?^{141}$ Courts and states must also consider whether there is rough proportionality between the number of majority-minority districts and the minority's share of the state's relevant population. ${ }^{142}$

Many factors play into whether a minority group can show that the answer to each of the above questions is "yes." For example, courts disagree as to when a minority group is "sufficiently large" enough to constitute a "majority." Some courts also use voting-age population

DiLuTion 1, 4 (Chandler Davidson ed., 1984) (stating that "[m]inority vote dilution" occurs when "the voting strength of an ethnic or racial minority group is diminished or cancelled out by the block vote of the majority" group).

${ }^{138}$ Gingles, 478 U.S. at 48-73 (establishing a three-pronged test for Section 2 claims based on geographic compactness, political cohesiveness among the minority group, and racial bloc voting among the majority group).

${ }^{139}$ Johnson v. De Grandy, 512 U.S. 997 (1994) (adding a proportionality requirement to the three-prong test adopted in Thomburg $v$. Gingles).

${ }^{140}$ Although not accepted as the universal definition, a majority-minority district is generally considered to be one in which a minority group constitutes an effective voting majority. See Johnson v. Miller, 864 F. Supp. 1356, 1360 n.2 (S.D. Ga. 1994) (defining a majority-minority district as one where the majority of the district's population are members of a single racial minority), affd, 515 U.S. 900 (1995); Shaw v. Hunt, 861 F. Supp. 408, 417 n.3 (E.D.N.C. 1994) (holding that a majority-minority district is one where "a majority of the registered voters and the voting age population are members of the same racial minority"), rev'd on other grounds, 517 U.S. 899 (1996); HEBERT ET AL., supra note 11, at 22-24 (discussing Gingles's definition of a "majority-minority" district). While outside the scope of this Comment, it is important to note that in 1993 the Court limited the role that race is permitted to play in redistricting. Shaw v. Reno, 509 U.S. 630, 647 (1993).

${ }^{141}$ HEBERT ET AL., supra note 11 , at 23.

142 Id. at 24-25; see also De Grandy, 512 U.S. at 1000 (holding that while "proportionality is not dispositive in a challenge to single-member districting," it is nevertheless "a relevant fact ... to be analyzed when determining whether members of a minority group have "less opportunity than other members of the electorate to participate in the political process and to elect representatives of their choice." (quoting 42 U.S.C. $\$$ 1973)).

Some courts have used a simple majority threshold (i.e., greater than fifty percent of the population) to determine whether a minority population is "sufficiently large" to create a majority-minority district, while others have used the concept of an "effective voting majority" (i.e., enough minority voters to elect candidates of their choice). Compare Stabler v. Thurston County, 129 F.3d 1015, 1022 (8th Cir. 1997) 
as a measure of the relevant population in lieu of total population figures in analyzing Section 2 claims. ${ }^{144}$ There is also a debate regarding how courts are to determine minority political cohesiveness and the degree of racial polarization. ${ }^{145}$ If a minority community can satisfy Section 2's three-prong analysis, then an argument similar to the one made for Section 5 can be advanced. ${ }^{146}$ The process of counting prisoners-who have potential to vote ${ }^{147}$ - as part of the population of the congressional district where they are held may fragment or pack an effective minority voting majority.

\section{Possible SOLuTIONS}

The Supreme Court has never specifically addressed the constitutional implications of applying the usual residence principle to disenfranchised prisoners, and lower courts are in disagreement as to the

(upholding district court's use of total population), and Houston v. Lafayette County, 20 F. Supp. 2d 996, 997-99 (N.D. Miss. 1998) (using total population as the basis for evaluating a Section 2 claim), with Barnett v. City of Chicago, 141 F.3d 699, 702 (7th Cir. 1998) (holding that "in order to constitute an effective majority," minorities "must be at least 65 percent of the total population of a district in order to be able to elect" a candidate of their choice), and Colleton County Council v. McConnell, 201 F. Supp. 2d 618, 642 (D.S.C. 2002) ("We measure equal opportunity by the percentage of minority age voting population necessary for the minority voters to elect the candidate of their choice ....").

${ }^{144}$ For example, the Seventh Circuit held that:

The threshold requirement roughly measures minority voters' potential to elect candidates of their choice. Because only minorities of voting age can affect this potential, it is logical to assume that the Court intended the majority requirement to mean a voting age majority. Viewed another way, those ineligible to vote have not experienced a dilution of their vote. They are not parties to a section 2 claim.

McNeil v. Springfield Park District, 851 F.2d 937, 945 (7th Cir. 1988); see also Clark v. Putnam County, 293 F.3d 1261, 1263 n.2 (11 th Cir. 2002) ("In a majority-minority district, a majority of the voting age population is from the minority population." (emphasis added)); NAACP v. Fordice, 252 F.3d 361, 366 (5th Cir. 2001) (evaluating minority plaintiffs' Section 2 claims based on "African-American majority voting age population districts").

${ }^{145}$ In Gingles, the Supreme Court approved the use of ecological correlation and regression analysis to determine racial polarization. 478 U.S. at 52-53. For other factors that courts have considered in determining political cohesiveness and racial polarization, see HEBERT ET AL., supra note 11, at 33-43.

${ }^{140}$ See supra Part VI.A (discussing potential Section 5 arguments against the usual residence principle as applied to prisoners).

${ }^{147}$ As discussed below, infra text accompanying notes $163-164$, it is relevant not only that these prisoners have no potential to vote, but that their interests will not be adequately represented by the majority of people that do. 
issues that would guide its analysis. I suggest two possible solutions to this constitutional conundrum.

\section{A. Count Prisoners at Their Last Residence of Record}

Doing away with the usual residence requirement, at least as applied to prisoners and disenfranchised former prisoners, is the least legally problematic solution to this constitutional puzzle. An act of Congress would be required to override the administrative policy of the Census Bureau. ${ }^{148}$ Such an act would direct census officials to count prisoners as residing at their last address of record. ${ }^{149}$ In lieu of an act of Congress, the Court would have to step in and declare the usual residence rule unconstitutional as applied. The Third Circuit has addressed a challenge to Census Bureau practices. In Bethel Park $v$. Stans, ${ }^{150}$ the plaintiffs challenged the usual residence requirement as applied to college students, members of the military, and prison inmates. ${ }^{1.51}$ Their concern was not only its effect on the composition of congressional districts within their state, but on the apportionment of congressional seats between the states. ${ }^{152}$ The Third Circuit held that Congress had delegated responsibility for conducting the decennial census to the Census Bureau through the Secretary of Commerce and concluded that the usual residence principle was "a historically reasonable means of interpreting the Constitutional and legislative phrase 'whole number of persons in each State." "153 The court cursorily addressed the Bureau's policy as applied to "inmates of institutions," reasoning that such institutionalized individuals "often have no other fixed place of abode, and the length of their institutional stay is often indefinite. ${ }^{154}$ The court offered no evidence to support its

${ }^{148}$ Cf. Dep't of Commerce v. United States House of Representatives, 525 U.S. 316,326 (1999) (noting that Congress attempted to pass legislation overriding the Census Bureau's decision to use sampling in the 2000 Census, but ultimately failed to do so).

Cf. Oversight of the 2000 Census: Hearing on H.R. 1632 Before the Subcomm. on the Census, House Comm. on Gov't Reform, 106th Cong. 4 (discussing proposed legislation that would "attribute the counts of prisoners to their 'home state' or the State in which they were convicted").

${ }^{150} 449$ F.2d 575 (3d Cir. 1971).

151 Id. at 577 .

${ }^{152}$ Id.

${ }^{153} I d$. at 578; see also District of Columbia v. United States Dep't of Commerce, 789 F. Supp. 1179, 1188-89 (D.D.C. 1992) (holding that the Census Bureau's decision to count inmates at a Virginia prison operated by the District of Columbia as Virginia residents was not arbitrary or capricious).

${ }^{154} 449$ F.2d at 582. 
assertion that prisoners have no fixed address. ${ }^{155}$ If this is in fact true, the solution proposed below would be more appropriate.

\section{B. Do Not Count Prisoners for Redistricting Purposes}

Although much more controversial than the previous option, Congress could pass a law that prohibits states from including disenfranchised prisoners in their population base for redistricting. This proposition is controversial for two reasons. First, the Court has recognized that there may be serious Article I, Section 2 concerns with using a population base other than total population for redistricting purposes. ${ }^{156}$ Second, there are serious policy concerns with a law that may be considered to treat prisoners as non-entities.

In Kirkpatrick v. Preisler, ${ }^{157}$ the Supreme Court recognized that " $[t]$ here may be a question whether distribution of congressional seats except according to total population can ever be permissible under Article I, Section 2." ${ }^{158}$ In Burns v. Richardson, ${ }^{159}$ however, the Court stated:

Neither in Reynolds $v$. Sims nor in any other decision has this Court suggested that the States are required to include aliens, transients, shortterm or temporary residents, or persons denied the vote for conviction of crime, in the apportionment base by which their legislators are distributed and against which compliance with the Equal Protection Clause is to be measured.

The Bums and Reynolds Courts were addressing the redistricting of state legislative districts, however, not congressional districts. Because the Court has interpreted Article I, Section 2 as it applies to congressional districts more strictly than the Equal Protection Clause's application to state legislative districts, ${ }^{161}$ it is unclear whether the Court

${ }^{155}$ Even if this assertion can be proven, it can still be argued that prisoners should be counted for redistricting purposes at their last address of record, even if they reside in one of the thirteen states that permanently disenfranchises incarcerated adults. The argument would rest on the proposition that a prisoner's interests are better represented in the district from which they originate or that their interests would be ignored in the district in which they are imprisoned.

${ }^{156}$ See, e.g., Karcher v. Daggett, 462 U.S. 725, 731 (1983) ("If a state does attempt to use a measure other than total population [for redistricting] ... it may not do so in a haphazard, inconsistent, or conjectural manner."); see also supra note 113.

${ }_{57} 394$ U.S. 526 (1969).

If. Id at 534-35.

159384 U.S. 73 (1966).

${ }^{160}$ Id. at 92.

${ }^{161}$ See supra text accompanying notes 61-92 (comparing the one-person, one-vote 
would extend the Burns rationale to the redistricting of federal election districts.

Lower courts have taken different sides in this debate. Several courts have held that states must depend on total population figures from the decennial census for federal congressional redistricting. ${ }^{162}$ Those courts have reasoned that the Supreme Court's one-person, one-vote jurisprudence is more closely based on the principle of "[e]qual representation for equal numbers of people." 163 A representative is charged with representing everyone in her district, whether or not that person is a voter. Assuming that a representative would pay equal consideration to the interests of the prisoners in her district, whether or not such prisoners were included in the district's population base, removing prisoners from that base would result in unequal access to federal representatives across districts. In other words, if a Member of Congress must represent the interests of all individuals in her geographical congressional district even though some of those individuals were not counted for interstate reapportionment purposes, that representative may, in essence, be responsible for more people than a neighboring representative. Some courts have viewed this possibility as even more constitutionally problematic than the status quo. ${ }^{164}$

On the other hand, at least one court has rejected the proposition that Article I, Section 2 requires states to use decennial census figures in redistricting congressional districts. ${ }^{165}$ In Meeks $\%$. Avery, the United States District Court for the District of Kansas determined that the use of state-conducted census figures was a proper "exercise of judgment in the legislative process." ${ }^{166}$ These figures were based on "established residence" and excluded college students, inmates of penal institutions, and individuals living on military bases. ${ }^{167}$ The court reasoned

principle in the context of state legislative and congressional redistricting).

${ }^{162}$ See supra note 113 (describing cases where courts instructed states to utilize total population figures).

Garza v. County of Los Angeles, 918 F.2d 763, 775 (9th Cir. 1990) (quoting Kirkpatrick, 394 U.S. at 531).

${ }^{164}$ See supra text accompanying notes 76-83 (describing the Court's decisions mandating strict population equality among congressional districts).

${ }^{165}$ Meeks v. Avery, 251 F. Supp. 245, 249-50 (D. Kan. 1966); see also City of Detroit v. Sec'y of Commerce, 4 F.3d 1367, 1374 (6th Cir. 1993) (stating that "[i]f figures other than census count are the best population data available, the Supreme Court [has] not ... bar[red] their use" in redistricting).

${ }^{166}$ Meeks, 251 F. Supp. at 250.

167 Id. at 249 . 
that "[r] eferences in Article I, Sections 2 and 4; in Section 2 of the Fourteenth Amendment to the Constitution; and in 2 U.S.C.A. $§ 2 a$, to the enumeration of the population of the various states have to do with the apportionment of representatives among the states, not within them." 168

\section{CONCLUSION}

In this Comment, I have examined the propriety of counting imprisoned persons at their prison address for redistricting purposes. I have suggested that this practice runs afoul of both constitutional and statutory requirements. The Census Bureau's "usual residence" principle, as applied to disenfranchised prisoners and former prisoners, cannot be squared with the Supreme Court's one-person, one-vote jurisprudence. The Court has refused to protect prisoners stripped of the most fundamental right accorded citizens of a democracy-the right to vote. It is time for either Congress or the Court to protect law-abiding citizens from state legislatures that unfairly take advantage of the existence of a disenfranchised population when creating "equal" congressional voting districts. "We the People" demand nothing less. 


\section{APPENDIX: FELONY DisenfRANCHISEMENT LAWS \\ (AS OF NOVEMBER 1, 2003)}

\begin{tabular}{|c|c|c|c|c|c|}
\hline STATE & PRISON & PAROLE & PROBATION & EX-FELON & SOURCE \\
\hline Alabama & $\overline{\text { Yes }}$ & Yes & Yes & Yes & $\begin{array}{l}\text { ALA. CONST. } \\
\text { amend. } 579 \\
\text { (Michie Supp. 2002) }\end{array}$ \\
\hline Alaska & Yes & Yes & Yes & No & $\begin{array}{l}\text { ALASKA STAT. } \\
\$ 15.05 .030 \\
\text { (Michie 2002) }\end{array}$ \\
\hline Arizona & Yes & Yes & Yes & Yes' & $\begin{array}{l}\text { ARIZ. REV. STAT. } \\
\$ \S 13-904 \text { to } 13-906 \\
(2001)\end{array}$ \\
\hline Arkansas & Yes & Yes & Yes & No & $\begin{array}{l}\text { ARK. CONST. } \\
\text { amend. } 51, \S 11(4)\end{array}$ \\
\hline California & Yes & Yes & No & No & $\begin{array}{l}\text { CAL. ELEC. CODE } \\
\$ 2101 \text { (West 2003) }\end{array}$ \\
\hline Colorado & Yes & Yes & No & No & $\begin{array}{l}\text { COLO. CONST. } \\
\text { art. } 7, \$ 10 .\end{array}$ \\
\hline Connecticut & Yes & Yes & No & No & $\begin{array}{l}\text { CONN. GEN. STAT. } \\
\text { ANN. \$ 946a (2002) }\end{array}$ \\
\hline Delaware & Yes & Yes & Yes & Yes $^{2}$ & $\begin{array}{l}\text { DEL. CODE ANN. } \\
\text { tit. } 15, \$ 1701 \\
\text { (Michie Supp. 2002) }\end{array}$ \\
\hline $\begin{array}{l}\text { District of } \\
\text { Columbia }\end{array}$ & Yes & No & No & No & $\begin{array}{l}\text { D.C. CODE ANN. } \\
\S 1-1-1.02(7)(2001)\end{array}$ \\
\hline Florida & Yes & Yes & Yes & Yes & $\begin{array}{l}\text { FLA. STAT. } \$ \\
97.041 \text { (2) (b) (2002) }\end{array}$ \\
\hline Georgia & Yes & Yes & Yes & No & $\begin{array}{l}\text { GA. CODE ANN. } \\
\S 21-2-216 \text { (b) (2003) }\end{array}$ \\
\hline Hawaii & Yes & No & No & No & $\begin{array}{l}\text { HAW. REV. STAT. } \\
\text { \$ 831-2(a) } \\
\text { (Supp. 2001) }\end{array}$ \\
\hline Idaho & Yes & No & No & No & $\begin{array}{l}\text { IDAHO CODE } \S 18-310 \\
\text { (Michie 2003) }\end{array}$ \\
\hline Illinois & Yes & No & No & No & $\begin{array}{l}730 \text { ILL. COMP. STAT. } \\
5 / 5-5-5 \text { (West 2003) }\end{array}$ \\
\hline Indiana & Yes & No & No & No & $\begin{array}{l}\text { IND. CODE ANN. } \\
\$ 3-7-13-5 \\
\text { (West 2003) }\end{array}$ \\
\hline Iowa & Yes & Yes & Yes & Yes & $\begin{array}{l}\text { IOWA CODE } \\
\S \text { 48A.6(1) (2002) }\end{array}$ \\
\hline Kansas & Yes & Yes & Yes & No & $\begin{array}{l}\text { KAN. STAT. ANN. } \\
\$ 21-4615(2002)\end{array}$ \\
\hline Kentucky & Yes & Yes & Yes & Yes & $\begin{array}{l}\text { KY. CONST. } \$ 145 \\
(2002)\end{array}$ \\
\hline Louisiana & Yes & No & No & No & $\begin{array}{l}\text { LA. REV. STAT. ANN. } \\
\$ 18: 102 \text { (West 2003) }\end{array}$ \\
\hline Maine & No & No & No & No & Not applicable \\
\hline Maryland & Yes & Yes & Yes & $\mathrm{Yes}^{3}$ & $\begin{array}{l}\text { MD. ANN. CODE art. } \\
\text { EL, \& 3-102 (2003) }\end{array}$ \\
\hline Massachusetts & Yes & No & No & No & $\begin{array}{l}\text { MASS. ANN. LAWS } \\
\text { ch. } 51, \S 1 \\
\text { (Law. Co-op. 2003) }\end{array}$ \\
\hline Michigan & Yes & No & No & No & $\begin{array}{l}\text { MICH. COMP. I.AWS } \\
\text { ANN. } \$ 168.758 b \\
\text { (West 2002) }\end{array}$ \\
\hline Minnesota & Yes & Yes & Yes & No & $\begin{array}{l}\text { MINN. STAT. } \\
\$ 201.014 \text { (2002) }\end{array}$ \\
\hline
\end{tabular}




\begin{tabular}{|c|c|c|c|c|c|}
\hline STATE & PRISON & PAROLE & PROBATION & EX-FELON & SOURCE \\
\hline Mississippi & Yes & Yes & Yes & Yes & $\begin{array}{l}\text { MISS. CODE ANN. } \\
\$ 23-15-11 \text { (2003) }\end{array}$ \\
\hline Missouri & Yes & Yes & Yes & No & $\begin{array}{l}\text { MO. REV. STAT. } \\
\$ 115.133 \text { (2003) }\end{array}$ \\
\hline Montana & Yes & No & No & No & $\begin{array}{l}\text { MONT. CODE ANN. } \\
\$ 13-1-111(2002)\end{array}$ \\
\hline Nebraska & Yes & Yes & Yes & No & $\begin{array}{l}\text { NEB. REV. STAT. } \\
\$ 32-313(2003)\end{array}$ \\
\hline Nevada & Yes & Yes & Yes & Yes & $\begin{array}{l}\text { NEV. REV. STAT. } \\
\$ 293-540(2003)\end{array}$ \\
\hline New Hampshire & Yes & No & No & No & $\begin{array}{l}\text { N.H. REV. STAT. ANN. } \\
\$ 607-A: 2(2002) \\
\end{array}$ \\
\hline New Jersey & Yes & Yes & Yes & No & $\begin{array}{l}\text { N.J. STAT. ANN. } \\
\$ 19: 4-1 \text { (West 2002) }\end{array}$ \\
\hline New Mexico & Yes & Yes & Yes & No & $\begin{array}{l}\text { N.M. STAT. ANN. } \\
\$ 1-427.1 \\
\text { (Michie 2003) }\end{array}$ \\
\hline New York & Yes & No & Yes & No & $\begin{array}{l}\text { N.Y. ELEC. LAW } \\
\text { \$ 5-106 } \\
\text { (McKinney 2003) }\end{array}$ \\
\hline North Carolina & Yes & Yes & Yes & No & $\begin{array}{l}\text { N.C. GEN. STAT. } \\
\S 163-55(2003)\end{array}$ \\
\hline North Dakota & Yes & No & No & No & $\begin{array}{l}\text { N.D. CENT. CODE } \\
\$ 12.1-33-01(2003)\end{array}$ \\
\hline Ohio & Yes & No & No & No & $\begin{array}{l}\text { OHIO REV. CODE } \\
\text { ANN. } \S 2961.01 \\
\text { (West 2003) }\end{array}$ \\
\hline Oklahoma & Yes & Yes & Yes & No & $\begin{array}{l}\text { OKLA. STAT. ANN. } \\
\text { tit. } 26, \S 4101 \\
\text { (West 2002) }\end{array}$ \\
\hline Oregon & Yes & No & No & No & $\begin{array}{l}\text { OR. REV. STAT. } \\
\$ \$ 137.275,137.281 \\
(2001)\end{array}$ \\
\hline Pennsylvania & Yes & No & No & No & $\begin{array}{l}25 \text { PA. CONS. STAT. } \\
\text { ANN. } \$ 1301 \\
\text { (West 2003) }\end{array}$ \\
\hline Rhode Island & Yes & Yes & Yes & No & $\begin{array}{l}\text { R.I. CoNST., } \\
\text { art. } 2, \S 1\end{array}$ \\
\hline South Carolina & Yes & Yes & Yes & No & $\begin{array}{l}\text { S.C. CODE ANN. } \\
\text { \$ 7-5-120 } \\
\text { (Law Co-op. 2002) }\end{array}$ \\
\hline South Dakota & Yes & No & No & No & $\begin{array}{l}\text { S.D. CODIFIED LAWS } \\
\text { \$ 12-4-18 } \\
\text { (Michie 2003) }\end{array}$ \\
\hline Tennessee & Yes & Yes & Yes & Yes & $\begin{array}{l}\text { TENN. CODE ANN. } \\
\$ 40-20-112(2003) \\
\end{array}$ \\
\hline Texas & Yes & Yes & Yes & No & $\begin{array}{l}\text { TEX. ELEC. CODE } \\
\text { ANN. } \$ 13.001(\mathrm{a})(4) \\
\text { (Vernon 2002) }\end{array}$ \\
\hline Utah & Yes & No & No & No & $\begin{array}{l}\text { UTAH CODE ANN. } \\
\$ 20 \mathrm{~A}-2-101(2003) \\
\end{array}$ \\
\hline Vermont & No & No & No & No & Not applicable. \\
\hline Virginia & Yes & Yes & Yes & Yes & $\begin{array}{l}\text { VA. CODE ANN. } \\
\$ 24.2-101 \\
\text { (Michie 2003) } \\
\end{array}$ \\
\hline Washington & Yes & Yes & Yes & Yes & $\begin{array}{l}\text { WASH. CONST, art. 6, } \\
\text { \$3; WASH. REV. } \\
\text { CODE } \$ 29.01 .080 \\
(2003)\end{array}$ \\
\hline
\end{tabular}




\begin{tabular}{|l|c|c|c|c|c|}
\hline \multicolumn{1}{|c|}{ STATE } & PRISON & PAROLE & PROBATION & EX-FELON & \multicolumn{1}{c|}{ SOURCE } \\
\hline West Virginia & Yes & Yes & Yes & No & $\begin{array}{l}\text { W. VA. CODE } \\
\text { \$\$ 3-1-3, 3-2-2 (2003) }\end{array}$ \\
\hline Wisconsin & Yes & Yes & Yes & Yes & $\begin{array}{l}\text { WIS. STAT. } \\
\text { \$6.03(1)(b) (2002) }\end{array}$ \\
\hline Wyoming & Yes & Yes & Yes & No & $\begin{array}{l}\text { WYO. STAT. } \\
\text { 22-3-102(a) (i) } \\
\text { (Michie 2003) }\end{array}$ \\
\hline
\end{tabular}

\footnotetext{
'Permanently after second felony conviction.

${ }^{2}$ For five years after end of incarceration for some felony offenses.

${ }^{3}$ For three years after end of felony incarceration; permanently upon second conviction for a violent felony.

${ }^{4}$ Except for first-time nonviolent felonies.
} 